\title{
US- Turkey Strategic Rivalry in Syria and its Effects on the Future of the Kurds in Syria
}

\section{Karzan Omar Ali ${ }^{*}$}

Keywords: Syrian crisis, military interventions, rivalry, Islamic State, Kurds, PYD.

\section{https://doi.org/10.31271/jopss.10014}

\begin{abstract}
This paper will focus on the influence of international forces in the Syrian conflict, illustrating and analyzing their agendas, and will try to locate where the Kurdish issue fits into the overlapping motivations and strategies of international actors. Furthermore, it will also analyze how the Kurds have responded to Turkish and US interventions into the conflict. The researcher reached conclusions that without setting common ground and mutual understanding among the influential powers whose armies and policies involved in the war, there would be no stopping bloodshed in Syria. Concerning the Kurdish future, the Kurds cannot gain any advantage from the conflict without being cooperated and assisted by the west, especially the United States while they are facing the threats of the regional powers. That is why they need to align their interests according to the western interests. If they do not, their future will remain uncertain and unstable in the region.

$$
\begin{aligned}
& \text { يوختهى تويّزينهوه: } \\
& \text { كيّبركيّى ستراتيجى نيّوان ولّاته يهكگرتووه كان و توركيا له سوريا و }
\end{aligned}
$$

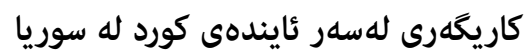

ئهم تويَزينهوهيه جهخت دهخاته سهر كاريكهرى هيّزه نيّودهولَهتيهكان له ململانيّى سوري سوريادا،

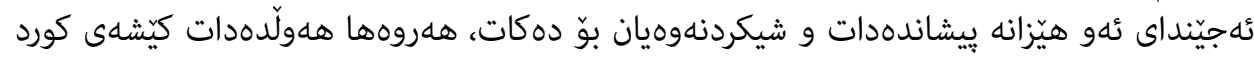

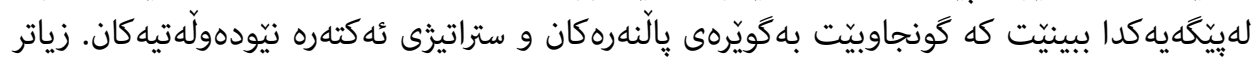

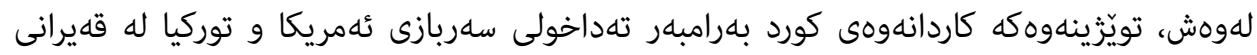

\footnotetext{
* Assistant Lecturer at College of Political Sciences - University of Sulaimani.

karzan.muhammed@univsul.edu.iq
} 


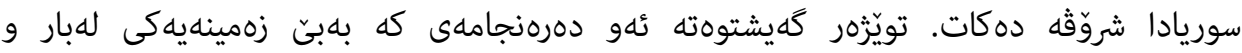

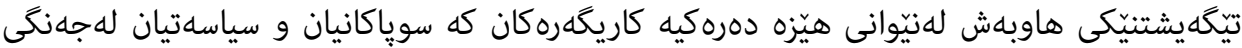

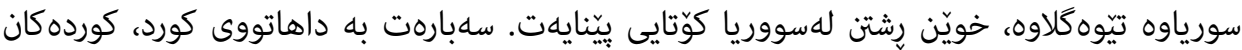

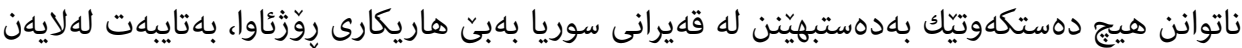

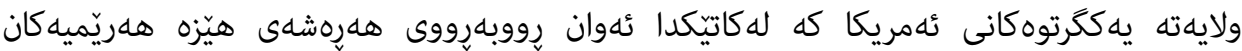

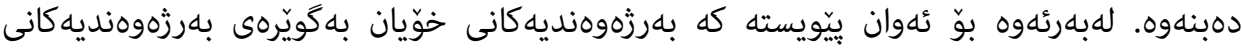

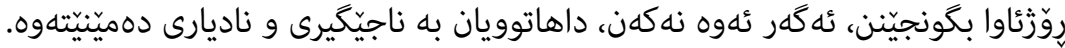

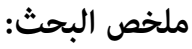

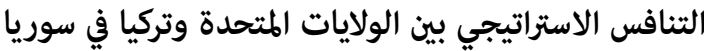 \\ وتأثيره على مستقبل الكورد في سوريا}

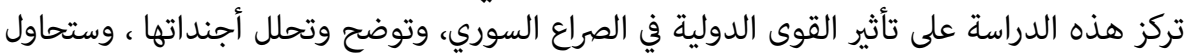

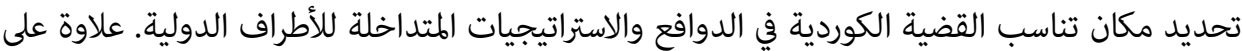

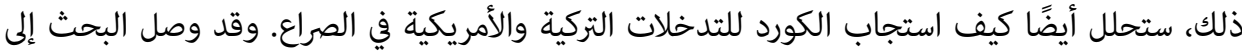

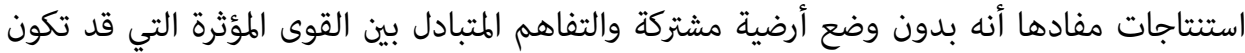

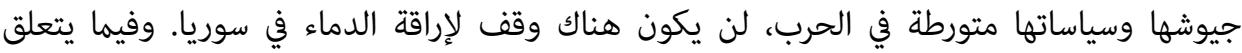

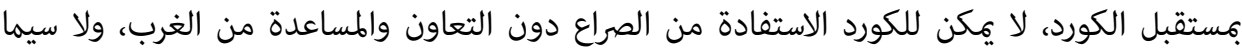

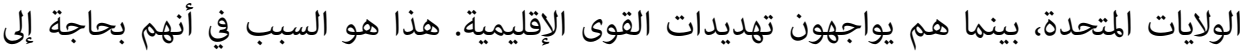

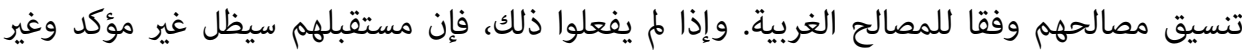
مستقر في المنطقة. 


\section{Introduction}

The Syrian war is one of the most lethal and complex conflicts in recent history. What started as a series of local demonstrations over economic issues soon turned into a widespread protest movement against the brutal regime of Bashar al-Assad, which then morphed into a civilian revolt against the Assad's government in 2011. Eventually, the conflict would evolve into a catastrophic civil war carried out simultaneously with a regional proxy war involving multiple interventions by a number of foreign actors. A decisive factor in the development of the latter was the rise of the Islamic State of Iraq and Syria (ISIS), which had established control over a large area of Syria and neighboring Iraq by 2014. This changed the political calculus of many in the West in particular and precipitated the intervention of coalition forces under the leadership of the United States against ISIS. Concurrently, the Russian government publicly entered the war to support the Syrian regime, which enabled Damascus to decisively turn the tide against Syrian rebels and retake sections of Syria that it had lost early in the war. In addition to this, regional players Iran and Turkey each intervened on opposite sides of the civil conflict with the former supporting Assad and the later backing the rebels. Nevertheless, they share a common opposition to the establishment of a Kurdish quasi-state in northeastern Syria, given that they are anxious about the effect that that may have on their own Kurdish populations. In essence, each foreign actor intervened for difference reasons, but, whatever their broader relationship, they may find themselves with competing or dovetailing interests in Syria.

This study focuses on how Turkey and the US approach the war in Syria and how their goals diverge in important ways, especially in relation to the Kurds, despite being allies with the context of the North Atlantic Treaty Organization (NATO). Both countries have a stand in opposition to the current Syrian regime, but in doing so support different local partners on the ground. The US' main local partner is the Kurds, specifically the People's Protection Units (YPG), who Turkey sees as a serious threat to its national security. The main question that this study seeks to answer is how the Kurds can navigate this situation, reaping benefits for themselves where they can, while avoiding pitfalls. This article will use a qualitative methodology and examine official statements, news stories, expert analysis, and other sources in an attempt to answer that question. It will also include the results of a number of semi- 
structured interviews that the author has conducted with relevant parties to help answer this question. As the Syrian Kurds attempt to navigate this complex environment with multiple foreign actors, it becomes clear that the most beneficial course of action that they can take is to align themselves with Western interest, in particular, those of the United States, in order to avoid an uncertain and unstable future.

First, this article will provide a general overview of the Syrian crisis, which foreign actors have intervened, and the motivations behind those decisions. Second, it will specifically focus on both the US and Turkish interventions as they relate to the Kurds and how this affects their bilateral relations. Finally, it will critically assess how the US and Turkish interventions have affected the Kurds' state-building project in northeastern Syria and its future prospects.

\section{1: Syrian Crisis and Military Interventions in it:}

\section{1-1: Syrian Crisis:}

Internally, the war in Syria is not strictly between two opposing sides. On the battlefield, there are multiple groups that operate as both primary actors and as proxies, primarily the Syrian regime, ISIS, armed Syrian opposition groups, and the Syrian Democratic Forces (SDF). The last of this is a multiethnic force but is dominated by the Kurdish Democratic Union Party (PYD) and its military branch, the YPG. Each of these groups has a different agenda for the future of the country, making the search for a political solution complex and prone to breakdowns. Syrian president Bashar al-Assad, whose government is based in Damascus, refused to step down from the power in the face of popular protests in 2011 and decided to use violence in order to remain in power. Most members of the international community have rejected the idea that he should remain in power. Consistently, the US, European leaders, and Turkey have claimed that Assad will not have a future in the political process of Syria and have used their influence and resources to oppose him to varying degrees. On the other hand, the regime's allies like Russia and Iran recognize Assad as the legitimate leader of the country and have directly intervened in Syria to keep him in power, arguably turning the tide in his favour when it appeared that he might be defeated by opposition groups on the ground. In September 2015, Russia launched a series of airstrikes in Syria, marking the 
beginning of a significant and sustained military intervention (Sladden, Wasser, Connable, and Clement, 2017). After obtaining strong support from Russia, it appears that the Syrian government and its ruler will be able to hold onto power for a long time, whereas the anti-regime forces have been steadily losing territory over the last several years.

From the beginning of the crisis, world powers were divided among themselves on how to deal with the Syrian issue. Assad and his backers have framed the conflict in terms of a fight between itself, the legal government, and various terrorist groups mostly came from outside the country. The US-led coalition has also framed its intervention as a counterterrorism operation, but its focus has always been ISIS. However, until September 15, 2015, the coalition forces were the only international forces to attack ISIS. For Assad, the presence of ISIS allows him to confuse the issue and, because of the ideological predilections of some of the Syrian rebels, position himself as an opponent of Islamic extremism, when he has actually done comparatively little to fight the transnational group. (Immenkamp, 2017)

Also confusing the issue is the regional spat between the Turkish and its affiliated partners, on the one hand, and Iran and its affiliated groups such as Hezbollah, on the other. Those proxy groups are in conflict with each other, but because of the Russian influence, Iran and Turkey have also worked together at times. (Zharov, 2016) Nevertheless, on the ground, the regional powers are divided on how to deal with the armed groups and at the same time how to redesign the future map of Syria.

In addition to these interventions, which focus more on the broader Syrian context, there have been two major interventions into Syria that involve the Kurds: one has been beneficial for the Kurds and one decidedly was not. First, the US and other Western powers have been supporting the YPG and Kurdish forces for several years in northeastern Syria in their fight against ISIS. The Coalition has supplied the Kurds with arms, provided advisers and training, and, crucially, conducted thousands of airstrikes against ISIS targets. These have been concentrated in Raqqa and Dier-e-Zor provinces. Second, the Turkish army launched an offensive into the Afrin region in the northwest corner of Aleppo province in January 2017. This region was one of the few places in Syria that had enjoyed security and stability compared to the rest of the country, but as a direct result of this military action 
against the Kurds, thousands of civilians were forced to flee their homes. As one can clearly see, there is a fundamental disconnect between the US and Turkey about the role and the future of the Kurds in Syria. The US sees the Kurdish-controlled area as a useful base of operations in order to enhance its strategy, manage the crisis, and hamper attempts to reshape the future of Syria without its influence. Turkey sees a Kurdish quasi-state in northern Syria as a safe haven for forces that will launch attacks against it. Turkey sees the PYD and YPG as an ideological and organizational offshoot of the Kurdistan Workers' Party (PKK) with which Turkey has been fighting a bloody conflict for several decades in its southeastern region. To that end, the Kurds must not only navigate the practical consequences of these two interventions but also somehow manage to not be caught up in the complicated interplay between the two NATO allies.

\section{1-2: A Brief Conceptualization of Foreign Military Intervention:}

The term 'intervention' has been used in International Relations to describe a number of different phenomena (Dos Santos, 2007), but, in recent decades, foreign military interventions have dominated the literature. (Pickering \& Kisangani, 2006) Explaining military interventions is not an easy task, because they are the result of a complex mix of historical, political, economic, personal, military, social, ethnic, and cultural factors (Chris, 2014). One common definition is that an intervention is 'the dictatorial interference by a state in the affairs of another state for the purpose of maintaining or altering the actual condition of things' (Oppenheim, 1955). Contemporary interventions are mostly involved countries undergoing serious socioeconomic and political crises and hope to achieve ambitious policy objectives ranging from ending civil wars, preventing humanitarian disasters, rebuilding failed states, to promoting human rights and democracy (Peksen, 2011). All of these aspects, however, tell us that military intervention is a process of one or more countries using force on another to achieve geopolitical, economic, and security goals.

\section{1-3: Foreign Military Interventions in the Syrian Crisis:}

The Syrian conflict offered an opportunity for regional and international powers to attempt to advance their foreign policy goals by intervening in the conflict, though each did so for different strategic goals. For the most part, their public justifications 
stated that they had done so in order to prevent a grave humanitarian situation from becoming worse. In this way, military intervention in the Syrian case is not like other historical interventions such as Iraq in 1991, in which the United Nations Security Council authorized coalition forces to launch an intervention on behalf of the aggrieved party of Kuwait. In the Syrian situation, there is no a clear UN permission to let any country to intervene its armed forces into Syria as it did in the Iraqi case (None to claim their bones, 2003). However, the UN has, on several occasions, passed resolutions designed to guide the conduct of the various sovereign actors fighting in Syria. The Security Council passed UNSCRs 2170, 2178, and 2199, which outline international responsibilities regarding countering terrorist financial resources, protecting the civilians from the battlefield (Farrell, 2014; McInnis, 2016). However, these do not authorize a full intervention into Syria, in the same way as those that authorized the intervention in Iraq and Kuwait. The UN Charter identifies two specific circumstances when it would do so:

(a) Collective armed intervention under auspices of the Security Council as a means of putting an end to a situation that constitutes a threat to the peace, a breach of the peace or an act of aggression.

(b) Individual or collective self-defence in cases where an armed attack occurred against a Member State of the United Nations. (Van der Vyver, 2017)

In the Syrian case, these do not apply. First, the Security Council resolutions to this point have largely been concerned with humanitarian and counterterrorism aspects of the conflict, not interstate security, a subject on which the Council has been deliberately vague. Second, unlike the situation between Iraq and Kuwait, the Syrian war began as a civil conflict, which limited the jurisdictional ability of the UN to do much more than observe and condemn. That is why many observers believe that the UN has failed to deal with the Syrian conflict. With this lack of a singularly defined mission, intervening countries were left to pursue their own goals in Syria. This created an exceedingly complex environment where actors with closely aligned interests elsewhere find themselves on opposing sides in Syria. This paper focuses on just such a situation, where two NATO allies working to reshape Syria in very different ways. 


\section{2: US and Turkey interventions in Syria Crisis}

\section{2-1: US Intervention and its Support for Kurds in Syria}

The US is very sensitive about protecting its allies in the Middle East from potential threats, providing Israeli with security from its foes, countering threats from Iran against the Sunni monarchies in the Persian Gulf, and actively fighting ISIS. In the last case, Islamic State horrified the world with its brutality, beheading and burning hostages without making any differentiation between civilians and armed fighters. On September 10, 2014, the US announced the formation of a broad international coalition to defeat ISIS (State Department, 2014). The US would eventually gather more than 65 states to accomplish this aim. Therefore, it is profitable to outline the significant goals of the US-led coalition forces in their Syrian intervention.

The first goal is to counter the threat of terrorist organization like ISIS and did so in a number of ways. First and foremost, it used its significant military might to deny ISIS territory and to degrade its military capabilities. In this, it was successful in stopping ISIS expanding its hold over large areas in Iraq and Syria and, in fact, has done much to shrink the areas that it controls. Coalition forces have also strongly countered ISIS' ability to fund itself through oil smuggling, human trafficking, and ransoms. (Gordon \& Schmitt, 2015)

Second, the Coalition has sought to limit Iran's agenda in the region. The US sees the Iranian regime as one of the primary sources of instability in the Middle East that aids and funds the Syrian government and militia groups like Hezbollah. There is a significant American interest in weakening what it sees as a radical axis of Iran, Syria, and Hezbollah, which actively works against American values and interests in the region. Nevertheless, both the US and Iran have fought ISIS and view the group as a threat. (Tabrizi, 2016) However, Iran's primary goal in Syria is aid the Assad regime, which we have seen profits to a certain degree from the chaos that is sown by ISIS. All of these factors have made the US wary about the Iranian role in Syria and establishing American bases and supporting loyal proxies in Syria can be useful in this regard.

The third goal is to reduce Russia's influence in the region by undermining and isolating Syria and enhance the US' role as a hegemonic power in the Middle East. The Syrian government from its founding has never been an ally of the United States 
but has been a good friend to Russia. Formulating an international coalition force to combat ISIS has also given the US a justification to extend its influence in Syria writ large. We can say that the American presence in Syria has weakened the Russian ambition to dominate Syrian affairs and fully impose its own agenda. Although Russia appears to be the most important external power in Syria at the moment, it must operate at times in cooperation with the US to achieve its goals. (McFaul, 2014)

The fourth goal is to expand the permanent presence of US bases in the region. Given that it was an arch-foe of the US, there were no active US military installations in Syria before the intervention against ISIS; today, there are more than ten. They are mostly located in the northeast of the country in Kurdish controlled areas and allow the US to impede Iranian geostrategic goals.

The fifth major goal is to protect Western allies such as Israel and Saudi Arabia from terrorism. Israel, as a staunch ally of the US and Saudi Arabia, is an oil-rich country with close military and economic ties to the United States. Additionally, both are staunch opponents of Iran.

While none of these goals is specifically designed to benefit the Kurds, it is clear that the Kurds' control of northeastern Syria allows the US to pursue its agenda and, as such, has demonstrated no apparent intention to leave Syria. Currently, given this, the US and Kurdish interest align and they will likely continue to operate in concert in Syria.

\section{2-2: Turkey intervention and its anti-Kurdish policy in Syria:}

As a regional power and neighbor to Syria, Turkey has had a vested interest in the outcome of the Syrian war but held off on directly intervening for a number of years. On August 24, 2016, however, it sent its army into northern Syria under the auspices of Operation Euphrates Shield to fight Islamic State and prevent the link-up of two Kurdish groups along the Turkish border. (Stein, 2017). It became more deeply involved in January 2017, when it and its militia partners from the Syrian Free Army invaded and occupied the Afrin region. Its foreign policy reflects its domestic interests, in particular limiting the growth and strength of Kurdish forces, countering the influence of Russia and Iran in its area of influence, and stemming the flow of Syrian refugees over its southern border.

Before the beginning of the chaos in Syria, Turkey did not have close ties with 
the Assad regime because of the strong relations between Damascus and Tehran, with whom Ankara has a simmering rivalry. (Lesch, 2017) This antipathy continued once the war began and Turkey became one of the strongest voices speaking against Assad on the international stage. Moreover, Turkey's historically complicated relations with Russia deteriorated after the shooting down of a Russian fighter jet near the border with Syria. Nearly all the bilateral relations between both countries were severed until the Turkish president apologized to his Russian counterpart by paying a visit to Moscow (Stubbs\& Dmitry, 2016). During that meeting, the two sides were able to make amends and establish the foundation for what is now a much stronger relationship. The result of this mutual understanding has been the Russians' tacit approval the Turkish intervention into Afrin to fight the YPG forces. Nevertheless, Turkey is loath to see either Tehran or Moscow as the dominant power in what it sees as its sphere of influence.

Second, Syrians now comprise one of the largest groups of refugee's worldwide, making up $32 \%$ of the 16.5 million refugees under the mandate of UNHCR and many of them reside in Turkey (Global Givin Team, 2018). The presence of so many refugees imposes a significant burden both on the Turkish state and on its economy. Turkish officials have stated that one of the reasons that they wanted to clear Afrin province of YPG forces was to pave the way for Syrian refugees to return to their homes (Fidan\&Alkan, 2018).

Unlike the US, Turkey has an explicitly stated interest in the Kurds and has sought to prevent the solidification of Kurdish control in northern Syria. The Kurdish problem in the Middle East is an unresolved issue that has an impact in Syria Turkey, Iraq, and Iran, each of which has a significant Kurdish minority within its borders. For Turkey, the establishment of any Kurdish quasi-state in Syria would be a real threat to its national security because of the ideological and organizational connections between the PKK and the YPG. To that end, it has taken directly to disrupt Kurdish ambitions. 


\section{3: US -Turkey Strategic rivalry in Syria}

\section{3-1: Turkey, US and the War on Terror in Syria}

The bilateral relationship between the US and Turkey has steadily deteriorated over the past several years, due in part because of the former's support for the YPG. That relationship was formalized during the siege of the Kurdish city of Kobane by ISIS starting in September 2014, when the Coalition launched airstrikes to support the YPG. Breaking that siege was a turning point in the fight against ISIS, where the militant group started to lose the territory it had captured. To build on that momentum, the US formed what is known as the Syrian Democratic Forces (SDF) to act as its proxy in that part of Syria. The SDF is technically a multiethnic force but is dominated by the YPG, which has drawn the ire of Turkey for the YPGs ties to the PKK. The US views the SDF as a most effective fighting force on the ground in Syria that is fighting against ISIS. Turkey counters that its own proxies in the Free Syrian Army are more deserving of US support than a group that is linked with the PKK, which the US has designated as a terrorist organization. While there have been serious efforts by the two allies to manage these differences, especially with regards to control of the strategic Syrian town of Manbij, they have been unable to bridge the divide fully and their disagreement over the Kurds has persisted. (Wilson Center, 2018).

\section{3-2: Turkey-US Rivalry and its effect on the Kurdish future:}

Throughout the Cold War, Turkey was an important bulwark in the US alliance system against the Soviet Union. (Aydin, 2004). But today, the situation has changed somewhat: on the one hand, there is no threat of communism spreading to Turkey, the Middle East, or the Mediterranean, while on the other hand, the Turkish ambition to act as a hegemonic regional power has grown in recent years, especially under the rule of the Justice and Development Party (AKP) and its leader, President Recep Tayyip Erdogan. On March 1, 2003, Erdogan decided that Turkey would not allow the deployment of foreign troops to its territory in order to attack Iraq (Barkey, 2011). The act of defiance was the first major example of a new relationship where the Turks and the Americans were aligned on many issues, but relations continued to suffer from serious disagreements.

Nowhere is that more apparent than on the issue of the Syrian crisis and the 
position of the Kurds in Syria. The Kurdish issue constitutes the main dividing line at present between Turkey and the United States in particular and the West in general. (Dalacoura, 2017). Turkey and the US in Syria are not working as the two strategic partners as they were before, but at least as awkward competitors. The attitudes of the two countries towards the internal and external actors in Syria are explained below in this table:

Country Syrian regime Syrian Sunni opposition groups ISIS Kurds Russia Iran

The United States Against the regime No high-level relationship Against ISIS Kurds are the main local partner to the US. Against Russian strategy to protect the current Syrian regime working to counter Iranian influence in Syria

Turkey Against the regime Major supporter to most of the Sunni armed groups, like Free Syrian Army Against ISIS Kurds are a major national security threat for Turkey Sees Russia as a card to be played in its relationship with the US Rival powers historically. Iran supports the Syrian regime; Turkey opposes it.

To that end, while there is some agreement on a few major issues in the Syrian conflict, such as the regime and ISIS, the US and Turkey clash most over their choice of proxies. The former works with the Kurds, who the Turks see as a major national security threat. Conversely, the Turkish government has chosen Sunni militias from the Free Syrian Army as its major proxies, which makes the US nervous because of the presence of Islamist groups, which the US opposes and has identified as being potentially harmful to its own national security.

The Kurds and those who support the establishment of a quasi-state in northern Syria, which I will call the 'Rojava project,' believe that they have experienced a high level of political, social, and cultural oppression from their various adversaries in most of the political regimes in the region, especially Turkey. Nevertheless, they feel excited about the positive attitude from the international community, in particular from the West. In an effort to cultivate that relationship, the Kurds will likely continue to emphasize that they are the only trusty local partner for the US on the ground in Syria and that any deterioration in relations with Turkey can be offset by having a stable and strong partner in northeastern Syria. Historically, the US has relied on Turkish bases to operate in the area, but having bases in Rojava provides an alternative that can be used to hamper Iran's attempts to expand its influences in the Middle East. Concerning Kurdish interests, recently, the US representative in Syria, 
Ambassador James Jeffery, mentioned two important points: first, he says that the US army will not leave Syria behind until Iran and its proxies move out of Syria and, second, the US supports the territorial integrity in Syria, with the caveat that they stand up for the constitutional and electoral rights of the Kurd in Syria. (The Times of Israel, 2018) This is the sort of hedge that the Kurds seek to cultivate.

Meanwhile, Turkey hopes to undermine the Rojava project by persuading the United States to review and ultimately terminate its de facto alliance with the YPG forces by positively emphasizing the other important aspects of Syria situation where Turkish and US interests align. However, Ankara has shown its willingness to use other measures as well to bring the US back to a strong relationship. First, it is trying to build up its Sunni proxies as an effective ground force in a way that will attract US support. (Young, Stebbins, Frederick \& Al-Shahery. 2014). Second, it has increased its diplomatic efforts with Washington's rivals to reduce the fighting in Syria. This makes Ankara attractive to Washington, in that the latter might be able to indirectly influence Moscow and Tehran. Third, it is playing hardball in terms of those relationships, in particular in terms of the military hardware contracts that the Trump administration values so highly. By suggesting that it may decide to buy Russian weapons, like the S-400 missile system, Turkey hopes to get the US to make a deal on the Kurds. To that end, Turkey is using both positive and negative inducements to bring the US over to its side regarding the Kurds.

\section{4: The Rojava Project: the Kurdish Struggle for Autonomy in Syria}

\section{4-1: Future Aspirations, Challenges and the role of PYD}

The Kurds constitute about $15 \%$ of the entire Syrian population. The vast majority of them, nearly two million people, live in an area covering about $15 \%$ of Syrian territory near the border with Iraq and Turkey (Hauser, 2017). In its modern history, Syria never recognized the national rights of Kurds, even denying citizenship rights to some of the population; nor did the dictatorial regime give social, economic and political rights to the Kurds. For these reasons, when the uprising broke out in 2011, the Kurds joined in the events and prepared themselves to fight for their rights in a new Syria. After seven years of the crisis, the destiny of the country remains unclear because of internal and external factors. Both the current regime and the other opposition groups do not support any form of Kurdish self-governance within 
Syria, which they want to return to being a centralized system. Since the First World War, the Kurds have fought for their national identity and for self-determination in the Middle East, but have not been successful at establishing an independent homeland. (Hiltermann, 2016) For many Kurds in Syria, they believe that the strategy of pursuing close relations with the United State will ultimately result in being rewarded with independence from Syria.

At the beginning of the crisis in 2011, the PYD was the most organized party in the Kurdish areas of Syria. It is part of a larger group of parties organized under the banner of the Democratic Society Movement in Western Kurdistan (TEV-DEM or Meclisa Gel ya Rojavayê). The PYD is publicly and firmly under the influence of the PKK's leader Abdullah Ochalan, who has been in prison in Turkey for more than 19 years. The PYD's main rival was the Kurdish National Council (KNC), whose own (similarly named) bloc National Council of Syria (ENKS \KNC) beings in smaller parties under the same umbrella. (Halhalli, 2018). ENKS has a close relationship with Kurdistan Democratic Party's KDP leader Masoud Barzani in Iraqi Kurdistan(Carnegie Center, 2012). The difference in sponsorship is the main difference between the two party blocs, as they both share the goal of achieving autonomy for Syrian Kurdistan. Whereas the PKK's main antagonist is the Turkish state, the Barzani and the KDP are seen as being close to Ankara. The fact that antiTurkish parties are ascendant in the Syrian Kurdish community is part of why the Turks have taken such a hard line against Kurdish autonomy in Syria.

In 2016, the ruling PYD declared that Kurdish-held territory to be a federal region within Syria called Rojava or Western Kurdistan. (The Economist, 2018) In doing so, the PYD has also established a decentralized, democratic model of governance, which has attracted the attention of many left-wing parties in Europe. (Orhan, 2016) Rojava consists of three regions - Afrin, Jazira, and Kobane - and each region contains two cantons. The representative of Rojava in the Kurdistan Region of Iraq, DrJawidan Kamal explained in an interview that the main purpose of formulating an autonomous region in northern Syria is not merely to benefit Kurds, but every Syrian citizen who wants to live inside the federation for political reasons. (Personal communication, July 03, 2018)( ). In general, the stated purposes of creating Rojava are to 1 ) to be a haven for people who have been victimized by the Assad regime, 2) to form a decentralized, democratic administrative and political 
structure as an alternative to Damascus, and 3) to highlight the Kurdish issue in the Middle East to create momentum towards creating an independent Kurdish state.

Although the Kurds were the main actor in northeastern Syria from the beginning of the conflict, it took the Siege of Kobane and the rise of ISIS for the US and the West to take them seriously as an effective proxy. However, once the US decided to begin supplying and aiding the Kurds, they emerged as a powerful symbol in the fight against the terrorism and brutality of ISIS in Syria. Apart from the narrative element, Kurdish control of a large swathe of territory in Syria gave the US and the Coalition valuable operational space. This close working relationship has also given the PYD and others the opportunity to showcase its ability to rule and govern a multiethnic space in conjunction with political parties and that it harbours common values with Western governments. As such, one can already see how Western and Kurdish goals began to dovetail after the rise of ISIS.

\section{4-1: Challenges in front of the Rojava Project:}

While the Syrian crisis and foreign military interventions in Syria at least opened a door for the Kurds to pursue the Rojava project, the process has not been without challenges, especially in the form of the Syrian government, its foreign backers, and Turkey, all of whom are wary of Kurdish determination anywhere in the region. Foremost, most of the foreign powers that have intervened in Syria have committed themselves to Syrian territorial integrity, including the US. Before the start of the war, the Kurds suffered under Assad's dictatorship regime: they had no national rights and expressions of their national identity were banned. Today, Assad associates Kurdish gains with unwelcome US influence in Syrian affairs, which is part of why he will not accept it. The head of the Democratic Society Movement (TEVDEM), AldarXalil, says that it is 'ready to resolve all the issues peacefully with the regime if it recognizes our fundamental national rights within democratic Syria. We believe in negotiation with every side of the conflict to make a deal about the future of Kurdish demand within Syria in which we as Kurds must have our autonomous region. It is not clear whether the regime accepts it or not' (Xalil, 2018) it remains to be seen whether the Assad regime will agree to any of this and, if it does not, what it will do regarding Rojava.

Second, Turkey poses a major challenge to Kurdish ambitions, especially given 
the closeness between the PYD and the PKK (Jeffrey \& Pollock, 2018). For Turkey, the Democratic Federation of Northern Syria is, at its essence, a challenge to the status quo in the Middle East and threatens Turkish national security interests. (Ereli, 2017) Although the Turkish aspect is one that is fundamentally premised on Turkish domestic concerns, it has a larger geopolitical element in it as well, due to the Turkish relationship with the US.

The third major challenge is posed by Russia, not because the Russians are opposed to the Kurds, but because Kurdish ambitions clash with its own geopolitical interests, namely supporting the Assad regime and competing with the US. Although Russia has tried to prepare a new constitution for Syria in which the rights of the Kurds are protected, it will not let any US strategic plans become a reality without a bilateral agreement. Due to the close relations between the YPG and the US-led coalition forces, Russia is not as enthusiastic as the US about the Rojava project. This is in part the reasons why it authorized the Turkish invasion of the Afrin Region.

Finally, there are intra-Kurdish challenges as well. While the PYD has strong support from the US and is a dominant political entity in Rojava, other Kurdish political groups hope to undermine and supplant the PYD, especially ENKS, which has a good relationship with Turkey. In an interview with the PYD representative in the Iraqi Kurdistan, Sleman Arab spoke about the main differences between the PYD and ENKS. First, ENKS more strongly supports Kurdish nationalism and, therefore, does not place as much emphasis on establishing a multiethnic government in Rojava. Second, the group has placed its faith in the Syrian National Council, which is hostile to decentralism and TEV-DEM. Third, they have different external patrons and have organized parallel and separate political and armed groups (Personal communication, July 08,2018$)($ ). This has led the two parties to take different sides on the Afrin issue, with the YPG/PYD fighting the Turkish invasion and ENKS supporting the Turkish operation. This intra-Kurdish division has served to undermine the Rojava project in ways that may harm its future ambitions, should it overcome the other challenges. What remains to be seen is the degree to which Turkey will be able to use its proxy to undermine that of the United States and vice versa. 


\section{Conclusion}

The Syrian conflict is exceedingly complex, with many overlapping layers of internal and external dynamics, and will not end in a way that achieves all the goals of even one actor. The conflict illustrates that state intervention by the global powers is largely not to stop the bloodshed, as interventionists often claim, but to advance a particular foreign policy agenda. Because of the divergent visions of the various foreign powers active in Syria and the fact that none are able to fully implement their vision over the others, the civil war continues. This paper has specifically looked at how the dynamics of intervention play out in relation to the Kurdish ambition to establish an autonomous space in Rojava or northeastern Syria and how Turkey and the US have played a part. The US and Turkey have not reached a joint policy between themselves yet concerning the future of Rojava. Each side supports a local partner who insists that its demands and policies be prioritized. On the one hand, Turkey sees an autonomous Kurdish area as a threat to its national security and territorial integrity, while the US sees it as a way of maintaining its influence in the region. This is complicated by the fact that elsewhere in Syria they actually share fundamental goals.

In order to realize their own ambitions, the Kurds need to put their own differences aside and cooperate between themselves to protect their achievements. Otherwise, they will live in an uncertain future because their own agenda will simply be swallowed up by that of the United States or Turkey. The Rojava project is a very hopeful strategic aspiration that will achieve fundamental Kurdish rights and institute a democratic political system where Syrians of all backgrounds are treated equally. It is clear that Rojava will continue to exist in some form as long as the United States does not completely abandon their proxy there. But, regionally, Turkey will also continue its attempts to undermine the project. International support for the Kurds in the future of Syria is essential, but at the same time, the degree that they have unity among themselves and that international actors cooperate with each other will be significant factors in their future within Syria. 


\section{References:}

1. Aydin, Mustafa, (2004, Dec), Turkish Foreign Policy Framework and Analysis, available at: http://sam.gov.tr/wpcontent/uploads/2011/12/mustafaaydin.pdf

2. Barkey J. H. (2011, June 6), Turkish Foreign Policy and the Middle East, CERI STRATEGY PAPERS $\mathrm{N}^{\circ} 10$ - RencontreStratégique du: available at: https://www.sciencespo.fr/ceri/sites/sciencespo.fr.ceri/files/n10_06062011.pdf

3. Carnegie Centrer, (2012, Feb 12). the Kurdish National Council in Syria, retrieved from: http://carnegie-mec.org/diwan/48502?lang=en

4. Chris, D. (2014, March 5). Which of The Military Intervention Theory That Best Explain Military Intervention In Nigeria And Reasons, retrieved from: http://chrisdonasco.blogspot.com/2014/03/which-of-military-interventiontheory.html

5. Dalacoura, Katerina, (2017, Feb), a New Phase in Turkish Foreign Policy: Expediency and AKP Survival, Middle East and North Africa Regional Architecture, available at: http://www.iai.it/en/pubblicazioni/new-phase-turkish-foreign-policy-expediencyand-akp-survival

6. Dos Satntos, A(2007), Military intervention and secession in South Asia: the cases of Bangladesh, Sri Lanka, Kashmir, and Punjab, PRAEGER SECURITY INTERNATIONAL, Westport, Connecticut • London, p (12).

7. Ereli, Adam, (2017, Nov 16). The Kurdish Explosion is Unleashing Demons, retrieved from: https://foreignpolicy.com/2017/11/16/the-kurdish-explosion-isunleashing-demons/amp/

8. Farrell, Theo (2014, Sep 23). Are the US-led air strikes in Syria legal - and what does it mean if they are not?. Retrieved from:

https://www.telegraph.co.uk/news/worldnews/middleeast/syria/11116792/Are-theUS-led-air-strikes-in-Syria-legal-and-what-does-it-mean-if-they-are-not.html

9. Fidan, Halil\&BehcetAlkan, Behcet. (2018, Mar 16). Overjoyed Syrians return to liberated homes in Afrin, retrieved from: https://www.aa.com.tr/en/middleeast/overjoyed-syrians-return-to-liberated-homes-in-afrin/1090670

10. Gordon, R. M \& Schmitt, E. (2015, Nov 12). U.S. Steps Up Its Attacks on ISISControlled Oil Fields in Syria, retrieved from:

https://www.nytimes.com/2015/11/13/us/politics/us-steps-up-its-attacks-on-isiscontrolled-oil-fields-in-syria.html?_r=0 
11. Global Giving Team (2018, May 01). Fast Facts about the Syrian Refugee Crisis, retrieved from: https://www.globalgiving.org/learn/listicle/syrian-refugee-crisisfacts/?rf=ggad_18\&gclid=EAIaIQobChMIsf-doYLo2wIVGsyCh2Hvw2KEAAYASAAEgKJ-vD_BwE

12. Halhalli, Bekir, (2018). Kurdish Political Parties in Syria: Past Struggles and Future Expectations, Springer, retrieved from : https://www.researchgate.net/publication/319684929_Kurdish_Political_Parties_in_S yria_Past_Struggles_and_Future_Expectations

13. Hauser, Zvi, (2017, Oct 03). Strengthen the Kurds in Syria, Oct 03, 2017, retrieved from: https://www.haaretz.com/opinion/.premium-strengthen-the-kurds-in-syria1.5455204

14. Hiltermann, Joost, (2016, May 19).The Kurds: A Divided Future?, retrieved from: https://www.crisisgroup.org/middle-east-north-africa/gulf-and-arabianpeninsula/iraq/kurds-divided-future

15. Beatrix Immenkamp, Beatrix, (2017 April), Syrian crisis: Impact on Iraq, European Parliamentary Research Service, available at: http://www.europarl.europa.eu/RegData/etudes/BRIE/2017/599387/EPRS_BRI\%2820 17\%29599387_EN.pdf

16. Jeffrey, F. J. \& Pollock, David, (2018, Jan 25). How to Stop the War Between Turkey and The Syrian Kurds?, retrieved from:

http://foreignpolicy.com/2018/01/25/how-to-stop-the-war-between-turkey-and-thesyrian-kurds/

17. Stubbs, Jack\& Solovyov, Dmitry, (June 27, 2016), Kremlin says Turkey apologized for shooting down Russian jet, Retrieved from: https://www.reuters.com/article/us-russia-turkey-jet-idUSKCN0ZD1PR

18. Zharov, Kirill, (2016, Dec 27). Turkey, Russia and Iran will hold a meeting on Syria in Moscow on December 27, retrieved from: http://tass.ru/mezhdunarodnaya-panorama/3873385

19. Lesch, W. D. (2017, Aug 29). Iran Is Taking Over Syria. Can Anyone Stop It?. Available at: https://www.nytimes.com/2017/08/29/opinion/iran-syria.html

20. McFaul, Michael, Stephen Sestanovich, Stephen \& Mearsheimer, J. John (2014). Faulty Powers: Who Started the Ukraine Crisis?, sep $\backslash$ oct,2014, retrieved from: http://mearsheimer.uchicago.edu/pdfs/Ukraine\%20Article\%20in\%20Foreign\%20Affai 
rs.pdf

21. Orhan, Oytun, (2016, August). Syrian Kurds: Current Political/ Military Situation And Foreign Affairs, Orasm Review Of Regional Affairs. Retrieved from: http://www.orsam.org.tr/files/Degerlendirmeler/48/48\%20Eng.\%20pdf

22. Oppenheim, L, (1995), 'Peace,' in International Law: A Treatise, vol. I, ed. H. Lauterpacht (London: Longmans, 305.

23. Pickering, J., \& Kisangani, E. (2006). Political, Economic, and Social Consequences of Foreign Military Intervention. Political Research Quarterly, 59(3), 363-376. Retrieved from: http://www.jstor.org/stable/4148037

24. Peksen, D. (2011). Foreign military intervention and women's rights. Journal of Peace Research, 48(4), 455-468. Retrieved from:

http://www.jstor.org/stable/23035207

25. Sladden, James, Wasser, BeccaConnable, Ben \& Sarah Grand-Clement, Russian, (2017). Strategy in the Middle East, RAND corporation, DOI: 10.7249/PE236,No:PE236-RC, 2017, available at:

https://www.rand.org/pubs/perspectives/PE236.html

26. Stein, Aron (2017, Feb). Reconciling U.S.-Turkish Interests in Northern Syria, Council of Foreign Relations, retrieved from: https://cfrd8files.cfr.org/sites/default/files/pdf/2017/02/Discussion_Paper_Stein_Syria _Turkey_OR.pdf

27. Wilson Center, ( 2018, June 5), State department Update on ISIS in Syria, Manbij Security, retrieved from: https://www.wilsoncenter.org/article/state-departmentupdate-isis-syria-manbij-security

28. The Global Coalition to Counter ISIL: A meeting of the Counter-ISIL Coalition in Brussels, (2014, Sep 10). Available at: https://www.state.gov/s/seci/

29. Tabrizi, B. A. (2016, August).Understanding Iran's Role in Syrian Conflict, Royal United Service Institute for Defense and Security Studies, available at: https://rusi.org/sites/default/files/201608_op_understanding_irans_role_in_the_syria n_conflict_0.pdf

30. The Times of Israel, (2018, Sep 28). US says will stay in Syria as long as Iran does, but maybe not military. Retrieved from: https://www.timesofisrael.com/us-says-willstay-in-syria-as-long-as-iran-does-but-maybe-not-militarily/

31. United Nations, (2003). Iraq/Kuwait - UNIKOM- Background, United Nation Iraq- 
Kuwait Observation Mission, available at:

https://peacekeeping.un.org/mission/past/unikom/background.html

32. Van Der Vyver, D. J. (2014, March 12). Military Intervention In Syria, The American, British And French Alternatives And the Russian Option, retrieved from: http://www.icla.up.ac.za/images/news/2014/johan_vd_vyver_lecture_12march2014_m ilitary_intervention_Syria.pdf

33. Xalil, Aldar, (2018, June 27).The Kurds are ready for negotiation with the Syrian Regime, Azhans Newspaper, pp. 6-7, retrieved from: https://en.calameo.com/read/004932797df2a505e1f9a

34. Youn, William, Stebbins, David, Fredreick A. Bryan\& Al-Shahery, Omer ( 2014), Spillover of the Syrian Conflict into Turkey, Rand Corporation, available at: http://www.jstor.org/stable/10.7249/j.ctt1287mhx.10 